\title{
From WWII to Kingston, Ontario: The History of Queen's University School of Medicine, Division of Plastic and Reconstructive Surgery
}

\author{
Karen Chung BHSc ${ }^{1}$, Kenneth Wyllie MD FRCSC ${ }^{2}$, John Davidson MSc MD FRCSC ${ }^{2}$
}

K Chung, K Wyllie, J Davidson. From WWII to Kingston, Ontario: The History of Queen's University School of Medicine, Division of Plastic and Reconstructive Surgery. Plast Surg 2016;24(3):171-173.

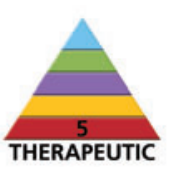

OBJECTIVE: To describe the origin and development of the Division of Plastic and Reconstructive Surgery at the Queen's University School of Medicine (Kingston, Ontario).

METHODS: Resarch ethics board approval and privacy agreements from the Kingston General Hospital (KGH, Kingston, Ontario) medical archives were obtained. Primary and secondary data sources were identified. A systematic examination of newspaper archives, research literature, $\mathrm{KGH}$ medical advisory committee meeting minutes, and testimonies from Dr Kenneth Wyllie and Dr John Davidson were obtained.

RESULTS: In 1949, Dr Albert Ross Tilley arrived at Queen's University in Kingston, Ontario. There, Tilley initiated the Burn Unit at the KGH and began monthly teaching during the academic semester. Ken Wyllie (Meds '55), Lloyd Carlson (Meds '57) and John Emery (Meds'57) were the notable progeny of his early initiatives. In 1963, Kenneth Wyllie founded the Division of Plastic and Reconstructive Surgery in Kingston, Ontario, having completed plastic surgery training in Toronto and Edinburgh with experiences in Stockholm (Sweden), Paris (France) and Baltimore (Maryland, USA). He was shortly joined by Pat Shoemaker (Meds '66). John Davidson (Meds '82) arrived in 1989, bringing an interest in microsurgery and critical inquiry to the division. Five notable surgeons, Cartotto (Meds '88), Watkins, Watters, Meathrel (Meds '03) and McKay, further enhanced the Division's clinical and academic mission.

CONCLUSIONS: The collective activity of the Division of Plastic and Reconstructive Surgery at Queen's School of Medicine in its 66-year history has encouraged more than 40 others to pursue distinguished careers in the specialty throughout North America, including three past presidents of the Canadian Society of Plastic Surgeons.

Key Words: History of plastic surgery; Ross Tilley; WWII

\author{
De la Seconde Guerre mondiale à Kingston, en \\ Ontario : L'histoire de la division de chirurgie \\ plastique et reconstructive de la faculté de \\ médecine de l'université Queen's
}

\begin{abstract}
OBJECTIF : Décrire les origines et l'évolution de la division de chirurgie plastique et reconstructive de la faculté de médecine de l'université Queen's, à Kingston, en Ontario.
\end{abstract}

MÉTHODOLOGIE : Les chercheurs ont obtenu l'approbation du comité d'éthique de la recherche et signé une entente de confidentialité avec les archives médicales du Kingston General Hospital (KGH) de Kingston, en Ontario. Ils ont établi des sources de données primaires et secondaires. Ils ont procédé à un examen systématique des archives journalistiques, des publications de recherche, des procès-verbaux du comité consultatif médical du KGH et des témoignages des docteurs Kenneth Wyllie et John Davidson.

RÉSULTATS : En 1949, le docteur Albert Ross Tilley est arrivé à l'université Queen's de Kingston, en Ontario. Il a créé la division des grands brûlés du KGH et s'est mis à donner des séances de formation mensuelles pendant le semestre universitaire. Ken Wyllie (promotion 1955), Lloyd Carlson (promotion 1957) et John Emery (promotion 1957) sont des émules remarquables de ces premières initiatives. En 1963, Kenneth Wyllie a fondé la division de chirurgie plastique et reconstructive à Kingston, en Ontario, après avoir acquis une formation en chirurgie plastique à Toronto et à Étdimbourg et de l'expérience à Stockholm (Suède), Paris (France) et Baltimore (Maryland, États-Unis). Il a vite été rejoint par Pat Shoemaker (promotion 1966). John Davidson (promotion 1982) est arrivé en 1989, avec un intérêt pour la microchirurgie et l'examen critique de la division. Cinq chirurgiens réputés, les docteurs Cartotto (promotion 1988), Watkins, Watters, Meathrel (promotion 2003) et McKay, ont amélioré la mission clinique et universitaire de la division.

CONCLUSIONS : Pendant ses 66 ans d'histoire, l'activité collective de la division de chirurgie plastique et reconstructive de la faculté de médecine de l'université Queen's a encouragé plus de 40 autres médecins à mener une carrière distinguée dans cette spécialité en Amérique du Nord, y compris trois anciens présidents de la Société canadienne des chirurgiens plasticiens.
T he objective of the present article is to describe the origin and development of the Division of Plastic and Reconstructive Surgery at the Queen's University School of Medicine (Kingston, Ontario). This is a tribute to the Division's leaders; Dr Ross Tilley, Dr Kenneth Wyllie, Dr Pat Shoemaker and Dr John Davidson. This division has since comprised a small but dynamic surgical service committed to exceptional student and resident education.

\section{METHODS}

Research ethics approval and privacy agreements from the Kingston General Hospital (KGH, Kingston, Ontario) medical archives were obtained. Primary and secondary data sources were identified. A systematic examination of newspaper archives, research literature, operation room registers, $\mathrm{KGH}$ medical advisory committee meeting minutes, and interviews with Dr Kenneth Wyllie and Dr John Davidson were conducted.

\section{RESULTS}

Dr. Ross Tilley was born in 1904 in Bowmanville, Ontario. He attended medical school at the University of Toronto (Toronto, Ontario) and graduated as a silver medalist in 1929 (1). During World War II (WWII), Dr Tilley served in the Royal Canadian Air Force (RCAF) medical service as a principal medical officer and devoted most of his time at the RCAF headquarters in the United Kingdom (1). In 1942, DrTilley transferred to Queen Victoria Hospital (QVH) in East Grinstead, Sussex. He worked alongside Sir Archibald McIndoe, a well-known surgical pioneer of WWII, contributed significantly to the 'Guinea Pig Club' and initiated the Canadian wing at QVH (2). In 1944, he was made an Officer of the Order of the British Empire for his leadership in pioneering new techniques for treating burns (2). After the war, Dr Tilley returned to Canada in 1945 as a highly skilled burn surgeon and practiced surgery in Kingston and Toronto (1). At the request of Dr DLC Bingham, the professor of

${ }^{1}$ Queen's University, Faculty of Health Sciences, School of Medicine; ${ }^{2}$ Queen's University, Faculty of Health Sciences, School of Medicine,

Department of Surgery, Division of Plastic and Reconstructive Surgery;

Correspondence: Ms Karen Chung, Faculty of Health Sciences, Queen's University, 15 Arch Street, Kingston, Ontario K7L 3 N6.

Telephone 905-719-7919, e-mail kchung@qmed.ca 


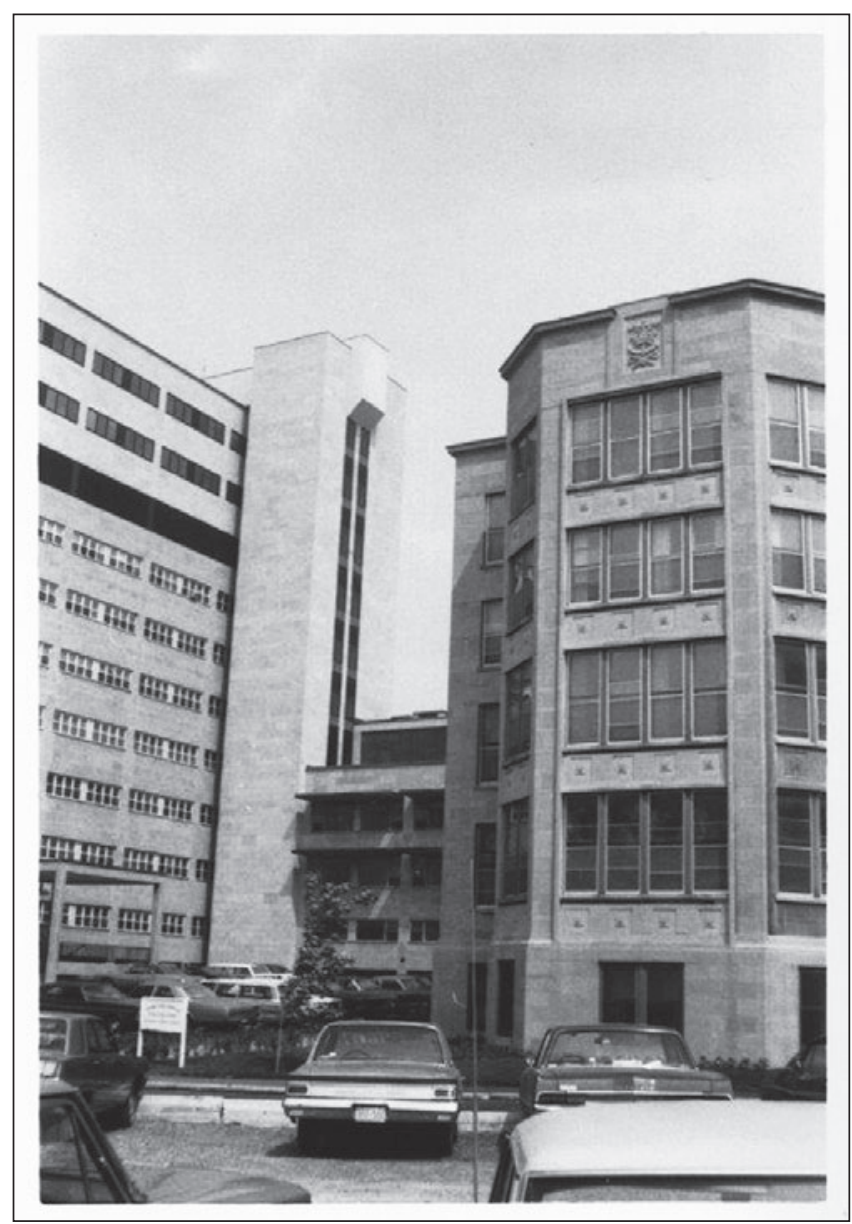

Figure 1) Exterior photo of the Victory Wing, 1947. Courtesy of the Kingston General Hospital Archives

surgery at Queen's University, Dr Tilley came to Kingston for three days every month during the academic semester at Queen's University and developed a burn unit on Victory 1 at KGH (Figure 1). He became an assistant professor of surgery in 1951 and was the first to teach plastic surgery to medical students at Queen's School of Medicine.

While Dr Tilley operated, Mr Kenneth Wyllie, as a fourth-year medical student, took every opportunity to watch and learn. Dr Wyllie graduated from Queen's School of Medicine in 1955 and interned with plastic surgeons Dr Alfred Farmer at The Hospital for Sick Children (Toronto, Ontario) and Dr Bill Lindsay at Sunnybrook Hospital (Toronto, Ontario). On recommendation from Dr Bingham, Dr Wyllie then completed his fellowship with Dr AB Wallace in Edinburgh, Dr Claude Dufourmontel in Paris (France) and Dr Milt Edgerton at John Hopkins (Baltimore, Maryland, USA). He returned to Kingston in 1963, and founded the Division of Plastic and Reconstructive Surgery. On his arrival, Dr Tilley left, leaving Dr Wyllie as the only plastic surgeon serving Kingston and the rural communities in James Bay (Figure 2).

The Division of Plastic and Reconstructive Surgery flourished under Dr Wyllie's leadership from 1963 to 1993. Dr Wyllie strongly believed in increasing the educational value of plastic surgery to students in Queen's undergraduate and postgraduate students. In 1964, plastic surgery became incorporated into the course curriculum for Queen's University School of Medicine. Then, as an advocate for patient care, Dr Wyllie pushed for occupational therapy and physiotherapy rehabilitation, additional beds and rooms in $\mathrm{KGH}$ and the development of the hand clinic to meet the growing needs of Kingston population. He received general surgery cases in decubitus ulcers, chronic leg wounds, and burns; orthopedic surgery cases of the hand

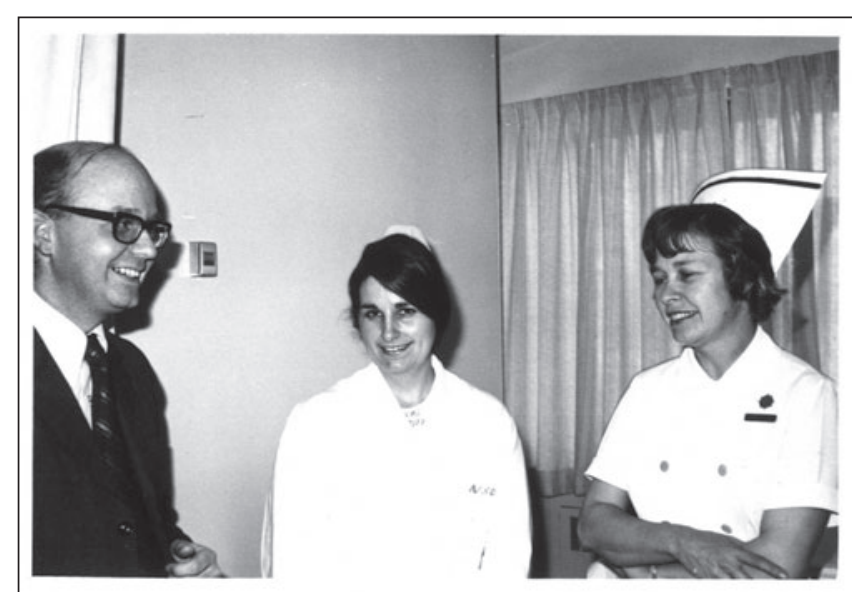

Figure 2) Dr Kenneth Wyllie, circa 1970. Courtesy of the Kingston General Hospital Archives

distal to the wrist; and urology cases in hypospadias-epispadias patients until their specialty program began pediatric urology. He also received difficult military plastic cases from the Kingston Military Hospital, which eventually moved to Ottawa (Ontario). Dr Wyllie was joined by Dr Paul Benoit, who shortly left for Ottawa (Ontario) and was replaced by Dr Patrick Shoemaker in 1975. They continued to meet needs in patients with congenital defects, developmental- defects of facial bones, trauma, peripheral neurovascular repair and grafting, cosmetic surgery, oral cancer, bony tumours of the hand and facial bones, and other neoplasms from the skin and related soft tissue.

In 1989, Dr John Davidson was hired as a long-awaited asset to the division. In addition to his clinical expertise in microvascular reconstruction, Dr Davidson initiated critical inquiry within the division and began to contribute scholarly research to the academic community. In 1993, Dr Wyllie retired, providing the opportunity for Dr Shoemaker to take his place as the head of the division, and for Dr Robert Cartotto to arrive and contribute expertise in burn critical care and clinical research. On the retirement of Dr Patrick Shoemaker in 2003, Dr Davidson was appointed head of the division. In 1999, Dr Frederick Watkins arrived and contributed his expertise in hand surgery. In 2004, Dr Conrad Watters briefly contributed his expertise in plastic surgery before departing in 2009. It was then that Dr Kimberly Meathrel arrived, contributing burn expertise after Dr Cartotto's departure, as well as her training in cosmetic surgery. Finally, in 2010, Dr Douglas McKay arrived as the final member, expanding the Division of Plastic and Reconstructive Surgery to meet the needs of patients who require cleft and pediatric craniofacial surgery.

\section{CONCLUSION}

The collective activity of the Division in its 66-year history has mirrored the development of plastic surgery in North America, and has encouraged more than 40 others to pursue distinguished careers in the specialty throughout Canada and in the United States, including three past presidents of the Canadian Society of Plastic Surgeons.

ACKNOWLEDGEMENTS: The authors thank Dr Jacalyn Duffin for her research support and passion for history of medicine projects, and Lorna Knight for enabling access to relevant Kingston General Hospital archives, photographs, medical advisory committee minutes, and operating room registers to successfully complete this project. Both figures are original photographs courtesy of the Kingston General Hospital Archives.

\section{REFERENCES}

1. Douglas LG. History of the Canadian Society of Plastic Surgeons. 1st edn. Quebec: Canadian Society of Plastic Surgeons; 1983.

2. Mowbrey K. Albert Ross Tilley: The legacy of a Canadian plastic surgeon. Can J Plast Surg 2013;21:102. 